\title{
Study on Antioxidant Potential and Nutrition Status of Different Underutilized Fruits in South Gujarat
}

\author{
Abuj B. B. ${ }^{1}$, N. Karmakar ${ }^{1 *}$, Vododariya P. R. ${ }^{1}$, Narwade, A. V. ${ }^{2}$ and Tripathi S. ${ }^{1}$ \\ ${ }^{1}$ Dept. of Soil Sceince and Agricultural Chemistry, ${ }^{2}$ Dept. of Genetics and Plant Breeding, N. M. College of Agriculture, Navsari \\ Agricultural University. Navsari, Gujarat (396 450), India
}

\section{Corresponding Author}

N. Karmakar

e-mail: nilimanau13@gmail.com

\author{
Article History \\ Article ID: AR1808b \\ Received in $15^{\text {th }}$ April, 2017 \\ Received in revised form $27^{\text {th }}$ June, 2017 \\ Accepted in final form $5^{\text {th }}$ August, 2017
}

\begin{abstract}
A survey experiment was carried out at in department of Soil Science and Agricultural Chemistry, N. M. College of Agriculture during 2015-2016 to determine antioxidant and biochemical potentials in some underutilized fruit crops of South Gujarat region. The experiment was undertaken in above mentioned minor fruits, which were collected from local cultivar of South Gujarat includes the districts of Navsari, Surat, Bharuch, Valsad, Tapi, Narmada and Dang. Amongst all the analyzed fruits, Emblica officinalis L. fruits was found to possess highest antioxidant content (31.35\%) followed by Artocarpus heterophyllus L. (25.18\%) and Zizyphus mauritiana L. (15.46\%), Tamarindus indica L. (8.50\%). The antioxidant contents viz., ascorbic acid63.57 mg $100 \mathrm{~g}^{-1}$, total phenol $31.06 \mathrm{GAE} 100 \mathrm{~g}^{-1}$, antioxidant enzymes like catalase (CAT) $33.38 \mathrm{U} \mathrm{g-I} \mathrm{fresh} \mathrm{weight,} \mathrm{superoxide} \mathrm{dismutase} \mathrm{(SOD)} 2.98 \mathrm{U} \mathrm{g}^{-1}$ fresh weight and peroxidase (POD) $9.79 \mathrm{U} \mathrm{g}{ }^{-1}$ fresh weight and antioxidant activity $74.18 \mu \mathrm{g} \cdot \mathrm{m}^{1-1}$ was reported higher in Emblica officinalis L. fruits collected Navsari, Pardi and Gandevi grown fruits of South Gujarat. Maximum content of biochemical parameters was obtained in Tamarindus indica L. (13.7071\%) fruits followed by Zizyphus mauritiana L. (12.52\%) and Artocarpus heterophyllus L. (8.127\%) fruits. The Biochemical contents viz., Total soluble solid

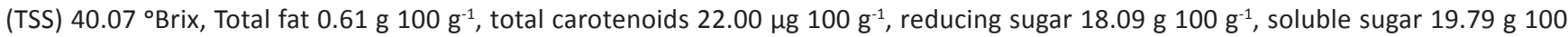

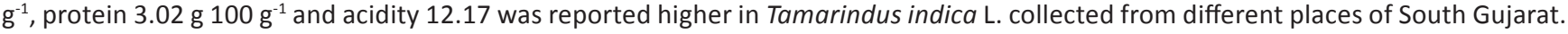
The consumption of these fruits as food supplements, their cultivation, conservation by the native tribal farming community should be encouraged in south Gujarat region.
\end{abstract}

Keywords: Ascorbic acid, antioxidant activity, total phenol, antioxidant enzymes

\section{Introduction}

Minor fruits are cultivated in lesser area compared to major fruits. This restricted cultivated fruits are also not abundant in market and usually are not cultivated in organised way. There are mainly four fruits come under the category of minor fruits, namely amla (Emblica officinalis L.), jackfruit (Artocarpus heterophyllus L.), tamarind (Tamarindus indica L.) and jujube (Zizyphus mauritiana L.) in the regions of south Gujarat (Hegde, 2009). Agro Industries Foundation has promoted the cultivation of these species on degraded hilly terrains in the Western Ghats region. Usually these tree plantations are maintained in local scale by the native user specially the tribal community of the South Gujarat for the fruits and the forest by products. Amla (Emblica officinalis L.) is one of the most celebrating plants in Indian traditional medicine, Ayurveda and are excellent source of various antioxidants. It is richest source of ascorbic acid (Khurana et al., 1970). An experiments conducted with the fruit of amla have been shown to possess antioxidant (Sultana et al., 2008) antibacterial and anti HIV (Eldeen et al., 2010). The use of herbal medicines in an evidence or science-based approach for the treatment and prevention of disease is known as phytotherapy. They are useful in vitiated conditions of tridosha, diabetes, cough, asthma, bronchitis, dyspepsia, colic, flatulence, hyperacidity, peptic ulcer, erysipelas, skin diseases, leprosy, haematogenesis, inflammations, anemia, emaciation, hepatopathy, jaundice, strangury, diarrhea, dysentery, hemorrhages, leucorrhoea, Menorrhagia, cardiac disorders, intermittent fevers and greyness of hair (Khurana et al., 1970) Jackfruit is an good source of antioxidants like Vitamin C, which helps to protect against viral and bacterial infections as well as strengthen the immune system function by supporting the white blood cells function. In addition to vitamin C, jackfruit is also rich in phyto-nutrients such as phenolics, flavonodies, lisoflavones which have anti-cancer and anti-aging properties. These phyto-nutrients may help to eliminate cancer causing free radicals from the body and 
slowing down the degeneration of cells that can lead to degenerative diseases (Priya et al., 2014). Tamarind has many valuable antioxidant properties and virtually every part of the tree has been utilized by both rural and urban dwellers. The most valuable and commonly used part of the tamarind tree is the fruit. The pulp constitutes $30 \%$ to $50 \%$ of the ripe fruit, the shell and fibre account for $11 \%$ to $30 \%$ and the seed about $25 \%$ to $40 \%$ (Shankaracharya, 1980). The jujube fruits have emollient and expectorant antioxidants properties (Kirtikar et al., 1935) The fruit is also considered to be cooling and an anodyne and a tonic. It employed as an antidote to aconite poisoning and is recommended in nausea and vomiting. The fruits are applied on cuts and ulcers; are employed in pulmonary ailments and fevers and mixed with salt and chili peppers are given in indigestion and Biliousness. There is some evidence suggesting that fruits and their products have protective effects against cancer, stroke and coronary heart diseases, which may relate to the presence of some biologically active compounds present in it (Kalt et al., 1999)

The present survey experiment had been under taken to explore the antioxidant and nutritional potentiality of the four types of fruits from the different places of South Gujarat and extend their cultivation to uplift the livelihood of the local people.

\section{Materials and Methods}

\subsection{Experimental site}

The present study was conducted at the Department of Soil Science and Agricultural Chemistry, N. M. College of Agricultural, Navsari Agricultural University, Navsari. during 2015-16. The fresh fruit samples of Amla (Emblica officinalis L.), Jackfruit (Artocarpus heterophyllus L.), Tamarind (Tamarindus indica L.) and Indian jujube (Zizyphus mauritiana L.) for experiment collected from local cultivar of South Gujarat includes the districts of Navsari, Surat, Bharuch, Valsad, Tapi, Narmada and Dang.

\subsection{Sample collection}

Fruits sample collected from Different places of South Gujarat such as Amla fruits collected from Navsari, Pardi, Karadi, Tapi, Hasapur and Gandevi, Jackfruit fruits collected from Navsari, Karadi, Hasapur, Bardoli, Songadh and Valsad, Tamarind fruits collected from Navsari, Dharampur, Valsad, Pardi, Chikhli and Dang and Indian jujube fruits collected from Navsari, Vyara, Dang, Dungri, Bardoli, and Aat

2.2.1. Sampling material : fresh and dry powdered fruit

2.2.2. Time of harvesting : edible maturity stage

\subsubsection{Sample preparation}

Fresh fruits at edible maturity stage were harvested from different plants and were subjected to different types of chemical analysis.

\subsection{Antioxidant parameters}

Ascorbic acid (vitamin-C) was determined by the dichloro phenol indophenols (DCPIP) titration procedure Casanas et al. (2002). The phenol content in the fresh tissue extract was measured by the Folin-Ciocalteau reagent using catechol by using Vinson et al., 2001 method. Catalase activity was estimated following the method of (Kar and Misra, 1976). The assay was based on the capacity of extracts to inhibit photochemical reduction of Nitro Blue Tetrazolium (NBT) in the riboflavin light- NBT system (Beauchamp and Fridovich, 1971). The method of Shanon (1966) was followed for analysis of peroxidase activity. The total antioxidant activity was determined using the 1, 1- diphenyl-2-picrylhydrazyl (DPPH) free radical scavenging assay (Koleva et al., 2002).

\subsection{Biochemical parameters}

TSS of pulp was measured with hand Refractometer (BM, India). Total fat content of the sample was determined by the procedure of AOAC (1984). Total carotene was analyzed spectrophotometrically using $\beta$-carotene as the standard (Singh and Bradbury, 1988). Reducing sugar content was estimated by Somogyi (1952) using arseno-molybdate reagent. The soluble sugar was determined by anthrone method as described by Timpa et al. (1985). Soluble protein content was determined by the procedure of Lowry et al. (1951). Acidity was determined according to the AOAC. (2000).

\section{Results and Discussion}

\subsection{Antioxidant contents}

\subsubsection{Antioxidant content of amla}

The variation in antioxidants contents was observed significant in amla fruits collected from six different sites of South Gujarat showed in table 01. Amla fruit juice had the higher content of ascorbic acid found grown in Hasapur side (660.67 mg $100 \mathrm{~g}^{-1}$ ) followed by Gandevi fruits (646.67 mg $100 \mathrm{~g}^{-1}$ ). The present finding was in agreement with the Kumar et al., 2006. Total phenolic content in amla fruit powder varies from 8738.00 mg GAE $100 \mathrm{~g}^{-1}$ and The estimated catalase activity level in different places of amla fruits ranged widely from 3285.71 to $3381.76 \mathrm{U} \mathrm{g}^{-1}$ fresh weight. The fruit extract of $E$. officinalis showed the highest catalase activity in Navsari fruits (3381.76 $\mathrm{U} \mathrm{g}^{-1}$ fresh weight) which is at par Karadi fruits (3374.76 U $\mathrm{g}^{-1}$ fresh weight), Hasapur fruits (3333.49 $\mathrm{U} \mathrm{g}^{-1}$ fresh weight) and Gandevi fruits (3339.57 $\mathrm{U} \mathrm{g}^{-1}$ fresh weight). The value of CAT activity is comparable with results of Vijayakumari et al. (2012). They reported Catalase activity in amla was varied from 3030.120 to $3533.333 \mathrm{U} \mathrm{g}^{-1}$ fresh weights respectively. There was no significant difference in mean values of SOD activity. However, numerically highest value of SOD activity was recorded in Gandevi location fruits (3.05433 $\mathrm{U} \mathrm{g}^{-1}$ fresh weight) followed by Navsari (3.0226 $\mathrm{U} \mathrm{g}^{-1}$ fresh weight). Goswami et al., 2010 amla fruit contain SOD activity about $9.247 \mathrm{U} \mathrm{g}^{-1}$ fresh weight of protein respectively. The maximum POD activity was showed in the Karadi grown fruits $(10.06 \mathrm{U}$ $\mathrm{g}^{-1}$ fresh weight) followed by Gandevi fruits (10.04 $\mathrm{U} \mathrm{g}^{-1}$ fresh weight). The amla fruit extracts POD activity ranges from 


\begin{tabular}{|c|c|c|c|c|c|c|}
\hline Location & 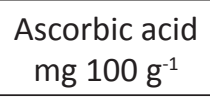 & $\begin{array}{c}\text { Total phenol mg } \\
\text { GAE } 100 \mathrm{~g}^{-1}\end{array}$ & $\begin{array}{c}\text { CAT } \cup g^{-1} \text { fresh } \\
\text { weight }\end{array}$ & $\begin{array}{c}\text { SOD } \cup g^{-1} \text { fresh } \\
\text { weight }\end{array}$ & $\begin{array}{c}\text { POD } \cup g^{-1} \text { fresh } \\
\text { weight }\end{array}$ & $\mathrm{DPPH} \mu \mathrm{g} \mathrm{m}^{-1}$ \\
\hline Navsari & 626.00 & 3101.02 & 3381.76 & 3.0226 & 10.03 & 73.83 \\
\hline Pardi & 641.67 & 3166.72 & 3316.69 & 2.8963 & 9.28 & 74.62 \\
\hline Karadi & 615.00 & 3100.96 & 3374.76 & 3.0176 & 10.06 & 73.89 \\
\hline Tapi & 624.67 & 3075.09 & 3285.71 & 2.9603 & 9.31 & 73.59 \\
\hline Hasapur & 660.67 & 3089.85 & 3333.49 & 2.944 & 10.03 & 73.88 \\
\hline Gandevi & 646.67 & 3105.67 & 3339.57 & 3.0543 & 10.04 & 74.18 \\
\hline Mean & 635.78 & 3106.55 & 3338.66 & 2.9825 & 9.79 & 74.00 \\
\hline SEm \pm & 16.874 & 31.469 & 35.985 & 0.0589 & 0.3849 & 0.357 \\
\hline $\mathrm{CD}(p=0.05)$ & 14.07163 & NS & 57.93014 & NS & 8.7928 & NS \\
\hline
\end{tabular}

NS: Non significant

$9.28 \mathrm{U} \mathrm{g}^{-1}$ fresh weight to $10.06 \mathrm{U} \mathrm{g}^{-1}$ fresh weight. Highest antioxidant activity was recorded in Gandevi location fruits $\left(74.18 \mathrm{\mu g} \mathrm{ml}^{-1}\right)$ followed by Karadi $\left(73.89 \mathrm{\mu g} \mathrm{ml}^{-1}\right)$ while lowest in Tapi $\left(73.59 \mu \mathrm{g} \mathrm{ml}^{-1}\right)$ respectively.

\subsubsection{Antioxidant content in jackfruit}

The perusal of data presented in table 02 revealed that the antioxidant contents of jackfruit collected from different places of South Gujarat. The ascorbic acid content in jackfruit collected from different places ranged from $7.47 \mathrm{mg} 100 \mathrm{~g}^{-1}$

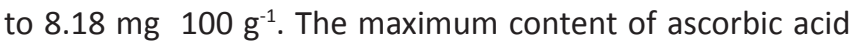

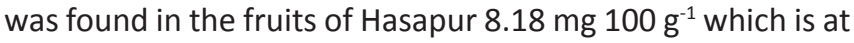

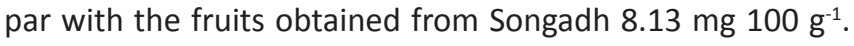
Goswami et al., 2010 found similar result to above finding of ascorbic acid in jackfruit of different places of Bangladesh. The total phenol content of jackfruit ranged between $(505.07 \mathrm{mg}$

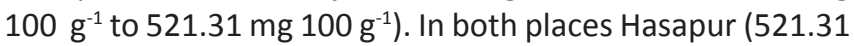
$\mathrm{mg} 100 \mathrm{~g}^{-1}$ ) and Songadh (521.31 mg $100 \mathrm{~g}^{-1}$ ) same content of total phenol was reported which is comparatively higher than other places. The result revealed similarity with the study
(Jagtap et al., 2010) stated that the amount of total phenol in

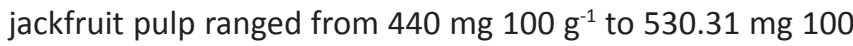
$\mathrm{g}^{-1}$. The higher catalase activity was detected in Hasapur region (1930.06 $\mathrm{U} \mathrm{g}^{-1}$ fresh weight) which is at par with fruits obtained from Bardoli (1929.31 $\mathrm{U} \mathrm{g}^{-1}$ fresh weight), Songadhn (1920.03 $\mathrm{U} \mathrm{g}^{-1}$ fresh weight) and Karadi (1916.94 $\mathrm{U} \mathrm{g}^{-1}$ fresh weight). The significantly higher content of catalase activity reported in Hasapur grown fruits. The SOD activity in jackfruit ranged from ( 2.71 to $2.43 \mathrm{U} \mathrm{g}^{-1}$ fresh weight) respectively. Maximum SOD activity was observed in Karadi (2.71 $\mathrm{U} \mathrm{g}^{-1}$ fresh weight) region followed by Navsari 2.66. Maximum POD activity was reported in Songadh region fruits $7.83 \mathrm{U} \mathrm{g}^{-1}$ fresh weight followed by Hasapur $7.62 \mathrm{U} \mathrm{g}^{-1}$ fresh weight. The antioxidant activity in jackfruit appreciably higher in Bardoli grown fruits $69.71 \mathrm{\mu g} \mathrm{ml}^{-1}$ followed by Navsari fruits $69.88 \mathrm{\mu g} \mathrm{ml}^{-1}$ region fruits The range of total antioxidant activity in different places was $69.71 \mathrm{\mu g} \mathrm{ml}^{-1}$ to $70.91 \mathrm{\mu g} \mathrm{ml}^{-1}$ respectively.

\subsubsection{Antioxidant content of tamarind}

The antioxidant potentials of tamarind fruits collected from

Table 2: Antioxidant content in jackfruit collected different places of South Gujarat

\begin{tabular}{|c|c|c|c|c|c|c|}
\hline Location & 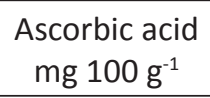 & 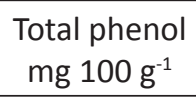 & $\begin{array}{c}\text { CAT } \cup g^{-1} \text { fresh } \\
\text { weight }\end{array}$ & $\begin{array}{c}\text { SOD } \cup g^{-1} \text { fresh } \\
\text { weight }\end{array}$ & $\begin{array}{c}\text { POD } \cup g^{-1} \text { fresh } \\
\text { weight }\end{array}$ & $\begin{array}{c}\mathrm{DPPH} \\
\mu \mathrm{g} \mathrm{ml}^{-1}\end{array}$ \\
\hline Navsari & 7.55 & 520.94 & 1910.03 & 2.66 & 7.59 & 69.88 \\
\hline Karadi & 7.47 & 517.61 & 1916.94 & 2.71 & 7.18 & 70.51 \\
\hline Hasapur & 8.18 & 521.31 & 1930.06 & 2.43 & 7.62 & 70.91 \\
\hline Bardoli & 7.59 & 517.10 & 1929.31 & 2.61 & 7.55 & 69.71 \\
\hline Songadh & 8.13 & 521.31 & 1920.03 & 2.52 & 7.83 & 70.22 \\
\hline Valsad & 7.80 & 505.07 & 1880.04 & 2.59 & 7.55 & 70.89 \\
\hline Mean & 7.78 & 517.22 & 1914.40 & 2.56 & 7.55 & 70.35 \\
\hline SEm \pm & 0.3058 & 6.2463 & 18.468 & 0.1001 & 0.2105 & 0.505 \\
\hline $\mathrm{CD}(p=0.05)$ & $0.1714721 \pm$ & NS & 18.70295 & NS & NS & NS \\
\hline
\end{tabular}

NS: Non significant 
different places of south Gujarat represented in table 03 . The ascorbic acid content in tamarind fruits was appreciably higher in Dharampur fruits (3.13 mg $100 \mathrm{~g}^{-1}$ ) followed by Navsari fruits $\left(2.89 \mathrm{mg} 100 \mathrm{~g}^{-1}\right)$. The lowest ascorbic acid content in tamarind pulp was observed in Chikhli fruits $2.43 \mathrm{mg} 100 \mathrm{~g}^{-1}$. Total phenol content was detected maximum in Chikhli region fruits (598.22 mg $100 \mathrm{~g}^{-1}$ ) which is at par with Navsari fruits (588.40 mg $\left.100 \mathrm{~g}^{-1}\right)$. Higher catalase activity was observed in
Valsad region fruits (240.07 $\mathrm{U} \mathrm{g}^{-1}$ fresh weight) followed by Dang (240.04 U g ${ }^{-1}$ fresh weight) and Chikhli (240.01 U g ${ }^{-1}$ fresh weight). The catalase activity of tamarind pulp ranges between (236.67 to $240.04 \mathrm{U} \mathrm{g}^{-1}$ fresh weight) respectively. Highest SOD activity was recorded in Dang tamarind fruits $\left(0.61 \mathrm{U} \mathrm{g}^{-1}\right.$ fresh weight) followed by Navsari and Dharampur tamarind fruits (0.60 $\mathrm{U} \mathrm{g}^{-1}$ fresh weight). POD enzyme activity in tamarind pulp ranged from $2.76 \mathrm{U} \mathrm{g}^{-1}$ fresh weight to $2.97 \mathrm{U} \mathrm{g}^{-1}$ fresh

\begin{tabular}{|c|c|c|c|c|c|c|}
\hline Location & $\begin{array}{c}\text { Ascorbic } \\
\text { acid mg } 100 \mathrm{~g}^{-1}\end{array}$ & $\begin{array}{l}\text { Total phenol mg } \\
\text { GAE } 100 \mathrm{~g}^{-1}\end{array}$ & $\begin{array}{c}\text { CAT } \cup g^{-1} \text { fresh } \\
\text { weight }\end{array}$ & $\begin{array}{c}\text { SOD } \cup g^{-1} \text { fresh } \\
\text { weight }\end{array}$ & $\begin{array}{l}\text { POD } \cup g^{-1} \text { fresh } \\
\text { weight }\end{array}$ & $\begin{array}{r}\text { DPPH } \\
\mu \mathrm{g} \cdot \mathrm{ml}^{-1}\end{array}$ \\
\hline Navsari & 2.89 & 588.40 & 239.96 & 0.60 & 2.96 & 29.29 \\
\hline Dharampur & 3.13 & 580.94 & 239.75 & 0.60 & 2.92 & 29.88 \\
\hline Valsad & 2.52 & 580.94 & 240.07 & 0.57 & 2.87 & 29.83 \\
\hline Pardi & 2.71 & 564.64 & 236.67 & 0.59 & 2.76 & 29.55 \\
\hline Chikhli & 2.43 & 598.22 & 240.01 & 0.59 & 2.88 & 29.31 \\
\hline Dang & 2.61 & 554.27 & 240.04 & 0.61 & 2.97 & 29.89 \\
\hline Mean & 2.71 & 577.90 & 239.42 & 0.59 & 2.89 & 29.62 \\
\hline SEm \pm & 0.2581 & 15.973 & 0.0136 & 0.013 & 0.0768 & 0.280 \\
\hline$C D(p=0.05)$ & NS & 14.155 & NS & NS & NS & NS \\
\hline
\end{tabular}

NS: Non Significant

weight. The highest POD enzyme activity was observed from tamarind fruit pulp of Dang fruits (2.97 $\mathrm{U} \mathrm{g}^{-1}$ fresh weight) followed by Navsari fruits ( $2.96 \mathrm{U} \mathrm{g}^{-1}$ fresh weight). Maximum total antioxidant activity recorded in Navsari fruits $(29.29 \mu \mathrm{g}$ $\mathrm{ml}^{-1}$ ) of South Gujarat.

\subsubsection{Antioxidant content of jujube}

The perusal of data presented in table 04 revealed significant variations in ascorbic acid content. The jujube fruit for present study were collected from six different location of South Gujarat. The results showed the highest ascorbic acid content found in fruits collected from Vyara $\left(76.19 \mathrm{mg}^{100 \mathrm{~g}^{-1}}\right)$ which is at par with Navsari fruits $\left(76.01 \mathrm{mg}^{\left.100 \mathrm{~g}^{-1}\right)}\right.$ and Aat

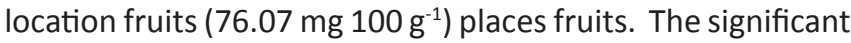
difference in ascorbic acid content of jujube fruits might be due to difference in edible maturity stage of fruits at the time of harvesting. The maximum content of total phenol reported

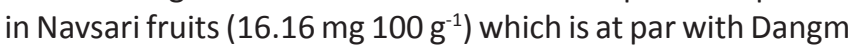
fruits $\left(16.13 \mathrm{mg} 100 \mathrm{~g}^{-1}\right)$. Thus the present finding was more or less similar with those reported by Krishna and Parasha, 2010. They reported amount of total phenol in jujube ranged

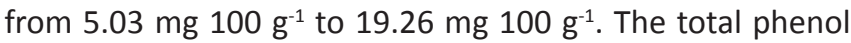

\begin{tabular}{|c|c|c|c|c|c|c|}
\hline Location & 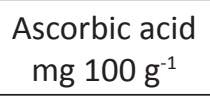 & $\begin{array}{l}\text { Total phenol mg } \\
\text { GAE } 100 \mathrm{~g}^{-1}\end{array}$ & $\begin{array}{c}\text { CAT } \cup g^{-1} \text { fresh } \\
\text { weight }\end{array}$ & $\begin{array}{c}\text { SOD } \cup g^{-1} \text { fresh } \\
\text { weight }\end{array}$ & $\begin{array}{c}\text { POD } \cup g^{-1} \text { fresh } \\
\text { weight }\end{array}$ & $\begin{array}{c}\text { DPPH } \\
\mu \mathrm{g} \mathrm{ml}^{-1} \\
\end{array}$ \\
\hline Navsari & 76.01 & 16.16 & 1469.84 & 1.94 & 0.618 & 41.94 \\
\hline Vyara & 76.19 & 15.65 & 1484.62 & 1.90 & 0.547 & 41.04 \\
\hline Dang & 75.90 & 16.13 & 1392.21 & 1.98 & 0.555 & 40.95 \\
\hline Dungri & 75.76 & 15.99 & 1436.50 & 1.92 & 0.592 & 41.45 \\
\hline Bardoli & 75.94 & 15.89 & 1382.17 & 1.89 & 0.610 & 41.33 \\
\hline Aat & 76.07 & 15.43 & 1353.53 & 1.88 & 0.580 & 41.32 \\
\hline Mean & 75.98 & 15.87 & 1419.81 & 1.92 & 0.584 & 41.340 \\
\hline SEm \pm & 0.1479 & 0.285 & 52.064 & 0.0371 & 0.028 & 0.35 \\
\hline $\mathrm{CD}(p=0.05)$ & 0.2038493 & 0.1537358 & 47.58 & NS & 0.024745 & 0.55624 \\
\hline
\end{tabular}

NS: Non Significant 
content in jujube fruit depend on the physical condition of plant. TP in jujube fruits increased from 40 to 48 days after leave fall of plant, decreased from 48 to 56 days after leave fall, again increased between 56 and 64 days after leave fall and decreased steadily after 64 days to maturity Lu et al., 2012. The higher content of TP in jujube fruits of Navsari might be due to this condition. The catalase activity in the jujube fruit collected from various locations South Gujarat differed significantly in present study. The fruit extract of jujube showed the highest catalase activity in Vyara fruits (1484.62 $\mathrm{U} \mathrm{g}^{-1}$ fresh weight units $\left.\mathrm{g}^{-1}\right)$ which is at par Navsari fruits (1469.84 $\mathrm{U} \mathrm{g}^{-1}$ fresh weight ), Dungari fruits (1436.50 g ${ }^{-1}$ fresh weight ). Numerically higher value was found in place Dang fruits $\left(1.98 \mathrm{U} \mathrm{g}^{-1}\right.$ fresh weight) followed by Navsari fruits (1.94U g ${ }^{-1}$ fresh weight) and Dungri fruits (1.92 $\mathrm{U} \mathrm{g}^{-1}$ fresh weight ). The range of SOD activity in jujube fruits was 1.88 to $1.98 \mathrm{U} \mathrm{g}^{-1}$ fresh weight respectively. Highest POD activity was observed in the jujube fruits of Navsari (0.618 $\mathrm{U} \mathrm{g}^{-1}$ fresh weight) which was at par with Bardoli grown fruits (6.10 $\mathrm{U} \mathrm{g}^{-1}$ fresh weight ). The antioxidant activity (DPPH scavenging activity IC50 $\mathrm{g} \mathrm{ml}^{-1}$ ) in different location of South Gujarat. Significantly higher content was found in Dang fruits $\left(40.95 \mathrm{~g} \mathrm{ml}^{-1}\right)$ Navsari fruits $\left(41.94 \mathrm{~g} \mathrm{ml}^{-1}\right)$, and fruits of Bardoli $\left(41.33 \mu \mathrm{g} \mathrm{ml}^{-1}\right)$ respectively. The value of antioxidant activity is comparable with results of Wei et al., 2005. They obtained DPPH scavenging IC50 $\mathrm{g} \mathrm{ml}^{-1}$ in jujube fruit ranged from 33.65 to $98.6 \mathrm{\mu g} \mathrm{ml}^{-1}$ respectively.

\subsection{Biochemical content}

\subsubsection{Biochemical content of Amla}

The results showed the highest TSS was found in Navsari (9.04 ${ }^{\circ}$ Brix) region (Table 5). Nayak et al. (2012) have reported higher total soluble solids (TSS) content of amla fruits (9.3 to 11.00 ${ }^{\circ}$ Brix) than present findings which might be due to variation in agro climatic conditions. Maximum TF content $0.13 \mathrm{~g} 100$ $\mathrm{g}^{-1}$ was obtained in fruits of Navsari followed by Hasapur fruits $\left(0.12{\mathrm{~g} 100 \mathrm{~g}^{-1}}^{-1}\right)$ though the difference of TF content in different place was non-significant. The fat content in amla was about

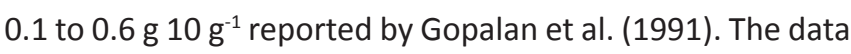
regarding to the carotene content in fruits of amla did not differ significantly. Maximum carotene content recorded same in Hasapur $57 \mu \mathrm{m} 100 \mathrm{~g}^{-1}$ followed by Navsari $56 \mu \mathrm{m} 100 \mathrm{~g}^{-1}$. The carotene content in above finding is lower than the USDA National Nutrient data base (2013). Maximum RS content

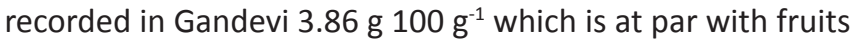

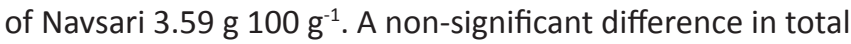
soluble sugar (SS) was observed among different locations of South Gujarat in amla fruits. Nayak et al. (2012) reported soluble sugar content of amla varied from 6.8 to $9.1 \mathrm{~g} 100$ $\mathrm{g}^{-1}$ which is slightly similar with our results respectively. TSP of amla fruit did not differ significantly in different location

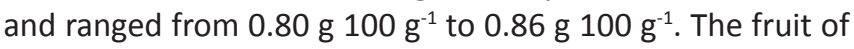
Hasapur was having the highest TSP content $0.86{\mathrm{~g} 100 \mathrm{~g}^{-1}}^{-1}$

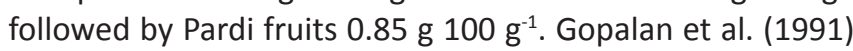
reported protein content in amla was about 0.5 to $1.0 \mathrm{~g} 100$ $\mathrm{g}^{-1}$ which are in agree with above findings. Significant variation in acidity in different places of South Gujarat was noted which

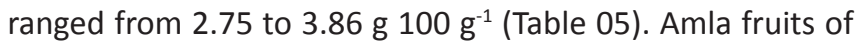

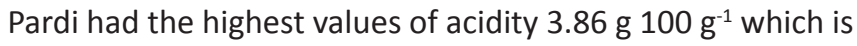

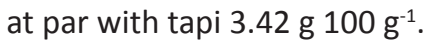

\subsubsection{Biochemical content of Jackfruit}

The results showed the highest TSS content in Karadi fruits $17.12^{\circ} \mathrm{Brix}$ which was at par with Songadh $16.99 \mathrm{~g}^{-1} 100 \mathrm{~g}^{-1}$ while the lowest in Bardoli fruits $16.36 \mathrm{~g} / 100^{\circ} \mathrm{Brix}$ which is at par with Hasapur fruits $16.45^{\circ} \mathrm{Brix}$. This result is similar to that reported by Haque (1991) ranged between $14^{\circ}$ Brix to $21.5^{\circ}$ Brix respectively. There was no significant differences in total fat content were observed among different locations of South Gujarat in jackfruit pulp (Table 6). Higher fat content

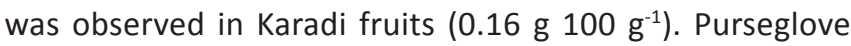
(1968) and Bhatia et al. (1955) reported similar fat content as above finding in jackfruit ranged from 0.15 to $0.22 \mathrm{~g}$ $100 \mathrm{~g}^{-1}$ respectively. The range of total carotene content in jackfruit pulp varied from $115 \mu \mathrm{g} 100 \mathrm{~g}^{-1}$ to $126 \mu \mathrm{g} 100 \mathrm{~g}^{-1}$

Table 5: Biochemical parameters of amla collected different places of South Gujarat

\begin{tabular}{|c|c|c|c|c|c|c|c|}
\hline Location & $\begin{array}{l}\text { TSS } \\
{ }^{\circ} \text { Brix }\end{array}$ & $\begin{array}{c}\text { Total fat } \mathrm{g} \\
100 \mathrm{~g}^{-1}\end{array}$ & $\begin{array}{l}\text { Carotene } \\
\mu \mathrm{g} 100 \mathrm{~g}^{-1}\end{array}$ & $\begin{array}{l}\text { Reducing sugar } \\
\quad{\mathrm{g} 100 \mathrm{~g}^{-1}}\end{array}$ & $\begin{array}{l}\text { Total soluble } \\
\text { sugar g } 100 \mathrm{~g}^{-1}\end{array}$ & $\begin{array}{l}\text { Soluble protein } \\
\qquad{\mathrm{g} 100 \mathrm{~g}^{-1}}\end{array}$ & $\begin{array}{l}\text { Acidity g } 100 \\
\mathrm{~g}^{-1}\end{array}$ \\
\hline Navsari & 8.65 & 0.13 & 56 & 3.59 & 6.54 & 0.83 & 2.75 \\
\hline Pardi & 8.99 & 0.10 & 54 & 3.02 & 6.88 & 0.85 & 3.86 \\
\hline Karadi & 8.60 & 0.11 & 56 & 3.42 & 6.61 & 0.80 & 3.20 \\
\hline Tapi & 8.67 & 0.11 & 55 & 2.89 & 7.03 & 0.83 & 3.42 \\
\hline Hasapur & 9.04 & 0.12 & 57 & 2.99 & 7.08 & 0.84 & 3.05 \\
\hline Gandevi & 9.00 & 0.11 & 55 & 3.86 & 6.60 & 0.86 & 2.86 \\
\hline Mean & 8.83 & 0.12 & 55 & 3.30 & 6.79 & 0.84 & 3.19 \\
\hline SEm \pm & 0.204 & 0.010 & 1.048 & 0.388 & 0.236 & 0.020 & 0.405 \\
\hline $\mathrm{CD}(p=0.05)$ & 0.165 & NS & NS & 0.598 & NS & NS & 0.579 \\
\hline
\end{tabular}

NS: Non significant 
in various places; however the effect of different places was not significantly differed (Table 6). Numerically higher value was found under place Navsari $126 \mu \mathrm{g} 100 \mathrm{~g}^{-1}$. Hossain and Haque (1979) found values of carotene in jackfruit pulp ranging

\begin{tabular}{|c|c|c|c|c|c|c|c|}
\hline Location & $\begin{array}{l}\text { TSS } \\
{ }^{\circ} \text { Brix }\end{array}$ & $\begin{array}{l}\text { Total fat g } \\
100 \mathrm{~g}^{-1}\end{array}$ & $\begin{array}{l}\text { Carotene } \\
\mu \mathrm{g} 100 \mathrm{~g}^{-1}\end{array}$ & $\begin{array}{l}\text { Reducing sugar } \\
\qquad \mathrm{g}^{100 \mathrm{~g}^{-1}}\end{array}$ & $\begin{array}{l}\text { Total soluble } \\
\text { sugar g } 100 \mathrm{~g}^{-1}\end{array}$ & $\begin{array}{l}\text { Soluble protein } \\
\qquad{\mathrm{g} 100 \mathrm{~g}^{-1}}\end{array}$ & $\begin{array}{l}\text { Acidity } \mathrm{g} \\
100 \mathrm{~g}^{-1}\end{array}$ \\
\hline Navsari & 16.87 & 0.11 & 126 & 10.79 & 13.90 & 1.15 & 0.46 \\
\hline Karadi & 17.12 & 0.16 & 115 & 10.79 & 13.89 & 1.13 & 0.45 \\
\hline Hasapur & 16.45 & 0.10 & 121 & 10.96 & 14.00 & 1.14 & 0.45 \\
\hline Bardoli & 16.36 & 0.11 & 118 & 11.02 & 14.36 & 1.15 & 0.48 \\
\hline Songadh & 16.99 & 0.10 & 120 & 10.85 & 14.01 & 1.16 & 0.47 \\
\hline Valsad & 16.60 & 0.09 & 118 & 10.90 & 13.93 & 1.13 & 0.43 \\
\hline Mean & 16.73 & 0.18 & 119 & 10.88 & 14.01 & 1.14 & 0.46 \\
\hline SEm \pm & 0.307 & 0.024 & 3.723 & 0.093 & 0.176 & 0.012 & 0.017 \\
\hline $\mathrm{CD}(p=0.05)$ & 0.22201 & NS & NS & NS & NS & NS & NS \\
\hline
\end{tabular}

NS: Non significant

from 250 to $1745 \mu \mathrm{g} 100 \mathrm{~g}^{-1}$ are near about reported in above findings. The different components of carbohydrate content like reducing sugar and total soluble sugar were not affected significantly due to variation in places. However, numerically higher value of reducing sugar and total soluble sugar were

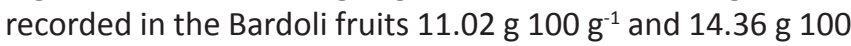
$\mathrm{g}^{-1}$. The value of reducing sugar was about $10 \mathrm{~g} 100 \mathrm{~g}^{-1}$ reported by Hossain and Haque (1979). The total soluble sugar varied

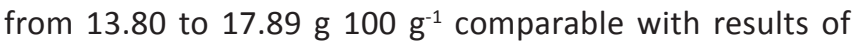
Goswami et al. (2011). Higher content of soluble protein was

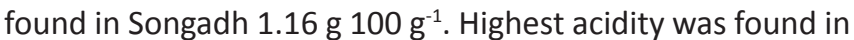
Bardoli (0.48 g $100 \mathrm{~g}^{-1}$ ) region whereas lowest acidity found

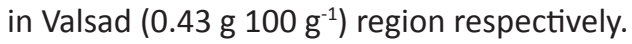

\subsubsection{Biochemical content of tamarind}

A very little difference in TSS content of that ranged from 39.75

${ }^{\circ}$ Brix to $40.07^{\circ}$ Brix was observed among tamarind fruits. The fruits of Pardi were having the highest TSS content followed by Dang $40.04^{\circ}$ Brix Valsad and Chikhli $40.01^{\circ}$ Brix grown fruits. The earlier work done by Anon (1982) reveled that TSS content

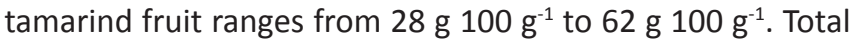
fat content in tamarind did not differ significantly in respect of different places of South Gujarat (Table 7). Maximum TF

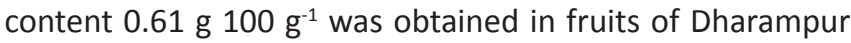
which was significantly higher compared to other cultivars. The result of above finding similar with reported by Coronel (1991); Feungchan et al. (1996). Maximum carotene content recorded same in Dharampur and Dang $22 \mu \mathrm{g} 100 \mathrm{~g}^{-1}$. The present finding was more or less similar with those reported by Duke (1981); Narasimham (1990). They reported amount of carotene content in jackfruits ranged from $20 \mu \mathrm{g} 100 \mathrm{~g}^{-1}$ to $25 \mu \mathrm{g} 100 \mathrm{~g}^{-1}$ respectively. The maximum value of reducing sugar and total soluble sugar was reported in Pardi side fruits

\begin{tabular}{|c|c|c|c|c|c|c|c|}
\hline Location & $\begin{array}{l}\text { TSS } \\
{ }^{\circ} \text { Brix }\end{array}$ & $\begin{array}{c}\text { Total fat g } \\
100 \mathrm{~g}^{-1} \\
\end{array}$ & $\begin{array}{l}\text { Carotene } \\
\mu \mathrm{g} 100 \mathrm{~g}^{-1}\end{array}$ & $\begin{array}{l}\text { Reducing sugar } \\
{\mathrm{g} 100 \mathrm{~g}^{-1}}\end{array}$ & $\begin{array}{c}\text { Total soluble } \\
\text { sugar g } 100 \mathrm{~g}^{-1}\end{array}$ & $\begin{array}{c}\text { Soluble protein } \\
{\mathrm{g} 100 \mathrm{~g}^{-1}}\end{array}$ & $\begin{array}{l}\text { Acidity g } \\
100 \mathrm{~g}^{-1}\end{array}$ \\
\hline Navsari & 39.96 & 0.60 & 21 & 16.95 & 19.30 & 3.02 & 12.08 \\
\hline Dharampur & 39.75 & 0.60 & 22 & 17.57 & 19.70 & 2.95 & 12.17 \\
\hline Valsad & 40.01 & 0.61 & 21 & 17.27 & 19.29 & 2.93 & 12.09 \\
\hline Pardi & 40.07 & 0.59 & 21 & 18.09 & 19.57 & 2.96 & 12.00 \\
\hline Chikhli & 40.01 & 0.59 & 21 & 17.74 & 19.79 & 2.99 & 12.10 \\
\hline Dang & 40.04 & 0.60 & 22 & 18.01 & 19.49 & 2.95 & 11.99 \\
\hline Mean & 39.97 & 0.60 & 21 & 17.61 & 19.52 & 2.97 & 12.07 \\
\hline SEm \pm & 0.115 & 0.007 & 0.516 & 0.438 & 0.204 & 0.032 & 0.067 \\
\hline$C D(p=0.05)$ & NS & NS & NS & NS & NS & NS & NS \\
\hline
\end{tabular}

NS: Non significant 


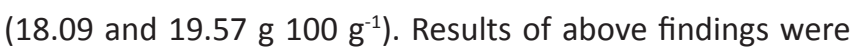
comparable to the reported results of Meillon (1974) and Parvez et al. (2003) in which reducing sugar ranged from

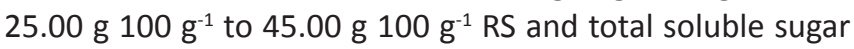
(SS) percentage also similar with findings of Marangoni et al.

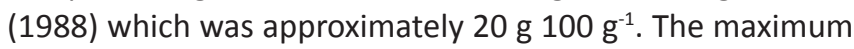

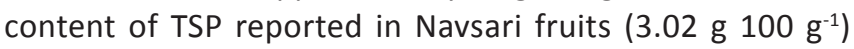

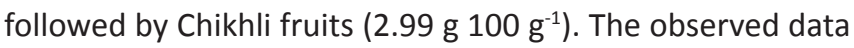
was supported by the work of Purseglove (1987) and Wenkam

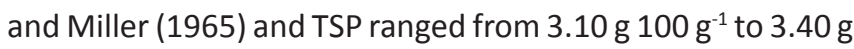
$100 \mathrm{~g}^{-1}$. Significant variation in acidity in tamarind of different places of South Gujarat was noted, which ranged from 11.99

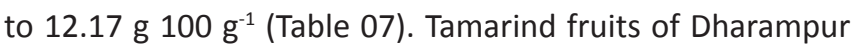

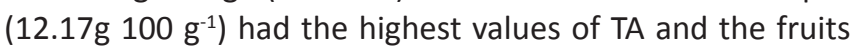

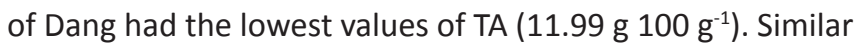

range of TA found by Meillon (1974) was from8.94 to 14.98 in tamarind.

\subsubsection{Biochemical content of jujube}

The data regarding to the TSS content in fruits of Indian jujube different location did not differ significantly (Table 8). Maximum TSS content recorded in Vyara $17.57^{\circ}$ Brix. According to Bhatia and Gupta (1985) total soluble solids ratio of Indian jujube was $16.70^{\circ} \mathrm{Brix}$ to $17.0^{\circ} \mathrm{Brix}$ which is more or less similar with above finding. Total soluble solids in various Indian jujube cultivars varied between 15 to $21^{\circ} \mathrm{Brix}$ (Chadha et al., 1972), whereas they observed TSS in Indian jujube cultivar Umran was $19^{\circ}$ Brix. Non significant differences in total fat content were observed among different locations of South Gujarat in Indian jujube fruit (Table 8). The higher total

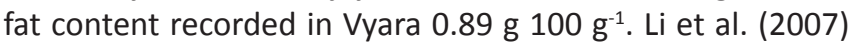

\begin{tabular}{|c|c|c|c|c|c|c|c|}
\hline Location & $\begin{array}{l}\text { TSS } \\
{ }^{\circ} \text { Brix }\end{array}$ & $\begin{array}{c}\text { Total fat g } \\
100 \mathrm{~g}^{-1}\end{array}$ & $\begin{array}{l}\text { Carotene } \\
\mu \mathrm{g} 100 \mathrm{~g}^{-1} \\
\end{array}$ & 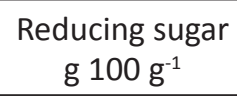 & $\begin{array}{c}\text { Total soluble } \\
\text { sugar g } 100 \mathrm{~g}^{-1}\end{array}$ & $\begin{array}{c}\text { Soluble protein } \\
{\mathrm{g} 100 \mathrm{~g}^{-1}}\end{array}$ & $\begin{array}{l}\text { Acidity } \mathrm{g} \\
100 \mathrm{~g}^{-1}\end{array}$ \\
\hline Navsari & 16.95 & 0.88 & 521 & 4.75 & 7.40 & 0.90 & 0.490 \\
\hline Vyara & 17.57 & 0.89 & 443 & 4.74 & 7.41 & 1.07 & 0.465 \\
\hline Dang & 17.27 & 0.85 & 428 & 5.69 & 7.94 & 0.99 & 0.409 \\
\hline Dungri & 18.14 & 0.88 & 483 & 4.73 & 7.03 & 1.15 & 0.472 \\
\hline Bardoli & 17.26 & 0.87 & 534 & 4.40 & 7.42 & 0.93 & 0.486 \\
\hline Aat & 17.08 & 0.87 & 511 & 4.53 & 7.60 & 1.11 & 0.420 \\
\hline Mean & 17.38 & 0.873 & 487 & 4.81 & 7.46 & 1.03 & 0.457 \\
\hline SEm \pm & 0.427 & 0.013 & 43.297 & 0.455 & 0.297 & 0.100 & 0.034 \\
\hline $\mathrm{CD}(p=0.05)$ & NS & NS & NS & NS & NS & 0.131 & 0.018 \\
\hline
\end{tabular}

NS: Non significant

reported that fat content in jujube varied from 0.37 to1.024 $\mathrm{g} 100 \mathrm{~g}^{-1}$, and the result of varied between the range 0.86 to

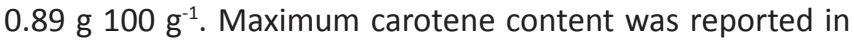
Bardoli region fruits $534 \mu \mathrm{g} 100 \mathrm{~g}^{-1}$ followed by Navsari fruits $521 \mu \mathrm{g} 100 \mathrm{~g}^{-1}$. The different parts of carbohydrate content like reducing sugar and total soluble sugar were not affected significantly in the Indian jujube fruits of different places. However, numerically higher value of reducing sugar and total soluble sugar were recorded with the Dang $5.69 \mathrm{~g} 100$

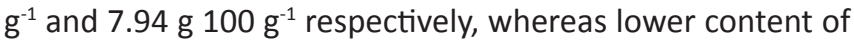

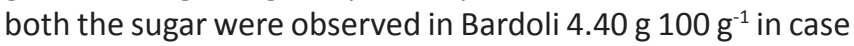

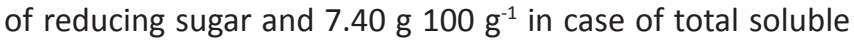
sugar in Navsari respectively (Table 8). The values of reducing sugar and total soluble sugar are comparable with results of Pareek and Dhaka (2008). Teotia et al. (1974) recorded total sugars and reducing sugars content of various Indian jujube cultivars and reported that the range for total sugars was 3.452 to $9.673 \%$ and that for reducing sugars was 3.274 to $9.77 \%$ respectively. Higher content of TSP was found in Dungri fruits

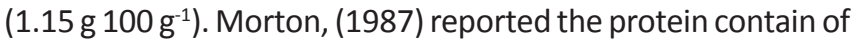

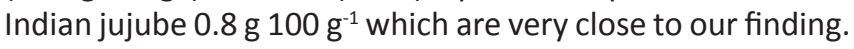

The maximum content of total soluble proteine was obtained in Dugri grown fruits of Indian jujube may be due to cultivars difference. The Yazao fruit cultivar difference had higher protein content compare to Jinsixiaozao, JianzaoJunzao and Sanbianhong cultivars of Indian jujube Li et al. (2007). There was significant difference in acidity content of Indian jujube fruits among different locations. Highest acidity was found in

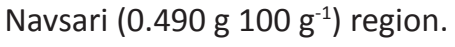

\section{Conclusion}

Minor fruits of this region is very much rich in antioxidants and nutritional parameters which can fulfill the nutritional need of the poor villagers of this region and not only that if it is cultivated in an economically with proper agronomic package and practice, for table purpose fruit it can fetch a fair amount of market price.

\section{References}

AAnon, 1982. Tamarind juice concentrate plant starts in Mysore. Indian Food Industry 1, 43-44. 
AOAC, 1984. Official methods of analysis, (14 ${ }^{\text {th }}$ Edn.), Association of official Analytic Chemist, Washington, D.C.

AOAC, 2000. Official Methods of Analysis (17 th Edn.), Association of Official Analytical Chemists, Arlington, VA, USA.

Bhatia, B.S., Siddappa, G.S., Lal, G., 1955. Composition and nutritive value of jackfruit. Indian Journal Agricultural Sciences 25(4), 30-36.

Bhatia, S.K., Gupta, O.P., 1985. Chemical changes during development and ripening of ber fruits. Punjab Horticultural Journal 24, 70-74.

Chadha, K.L., Melanta, K.R., Lodh and Selvaraj, Y., 1972. Biochemical changes associated with growth and development of pineapple variety Kew. I. Changes in physico-chemical constituents. Indian Horticulture 29(1), 53-57.

Coronel, R.E., 1991. Tamarindus indica L. In Plant Resources of South East Asia, Wageningen; Pudoc. No. 2. Edible Fruits and Nuts, E.W.M. Verheij and R.E. (Eds.), Coronel, PROSEA Foundation, Bogor, Indonesia, 298 - 301.

Duke, J.A., 1981. Handbook of Legumes of World Economic Importance. Plenum Press, New York, 228-230.

Eldeen, I.M.S., Seowa, E-M., Abdullah, R.,Sulaiman, S.F., 2011. In vitro antibacterial, antioxidant, total phenolic contents and anti-HIV-1 reverse transcriptase activities of extracts of seven Phyllanthus sp. South African Journal of Botany 77(1), 75-79.

Feungchan, S., Yimsawat, T., Chindaprasert, S., Kitpowsong, P., 1996. Tamarind (Tamarindus indica L.) Plant genetic resources in Thailand. Thai Journal of Agricultural Sciences 5(1), 1-11.

Gopalan, C., Sastri, B.V.R., Balasubramaniam, S.C., 1991. Nutritive value of Indian foods. NIN, Hyderabad, India, His Majesty's Government of Nepal, Ministry of Forest and Soil Conservation, Department of Medicinal Plants. Medicinal Plants of Nepal ( $3^{\text {rd }}$ Ed.), His Majesty's Government Press, Kathmandu, 185.

Goswami, C., Hossain, M.A., Kader, H.A., Islam, R., 2011. Assessment of Physicochemical Properties of Jackfruits' (Artocarpus heterophyllus Lam) Pulps. Journal of Horticulture, Forestry Biotechnology 15(3), 26-31.

Goswami, C., Hossain, M.A., Kader, H.A., Islam, R., 2011. Assessment of Physicochemical Properties of Jackfruits (Artocarpus heterophyllus Lam) Pulps. Journal of Horticulture Forestry and Biotechnology 15(3), 26-31.

Haque, M.A., 1991. Fruit characteristics of thirty two selected jackfruit trees of Bhaluka, Trishal and Kotwali thana of Mymensingh district. Proc. BAURES. Prog. 7, 209-215.

Hegde, N.G., 2009. Promotion of Underutilised Crops for Income Generation and Environmental Sustainability. In: Proceeding of the International Symposium on "Underutilised Plants for Food Security, Nutrition, Income and Sustainability Development", Arusha,
Tanzania. Organised by the International Centre for Under-utilised Crops (ICUC), Colombo. March 3- 7, Acta Horticulture 2, 563-569.

Hossain, M., Haque, A., 1979. Nutritive value of jackfruit. Bangladesh Agriculture 4(1), 9-12.

Jagtap, U.B., Panaskar, S.N., Bapat, V.A., 2010. Evaluation of antioxidant capacity and phenol content in jackfruit (Artocarpus heterophyllus Lam.) fruit pulp. Plant Foods and Human Nutrtion 65, 99-104.

Kalt, W., Forney, C.F., Martin, A., Prior, R.L., 1999. Antioxidant activity, vitamin $C$, phenolics, and anthocyanins after fresh storage of small fruits. Journal of Agricultural Food chemistry 47, 4638-4644.

Kar, M., Mishra, D., 1976. Catalase, peroxidase, polyphenol oxidase activities during rice leaf senescvence. Plant Physiology 57, 315.

Khurana, S.C., Gupta, S.K., Sharma, R.C., Arora, R.B., 1970. Study of pharmacodynamic properties of Emblica officinalis. Indian Journal of Physiology and Pharmacology 14, 39.

Kirtikar, K.R., Basu, B.D., 1935. Indian Medicinal Plants. $2^{\text {nd }}$ Edn., Lalit Mohan Basu, Allahabad, 3.

Koleva, I.I., Van Beek, T.A., Linssen, J.P.H., de Groot, A., Evstatieva L.N., 2002. Screening of plant extracts for antioxidant activity: a comparative study on three testing methods. Phytochemical Analysis 13, 8-17.

Krishna, H., Parasha, A., 2010. Phytochemical Constituents and Antioxidant Activities of Some Indian Jujube (Ziziphus mauritiana Lamk.) Cultivars. Journal of Food Biochemistry 37(5), 571-577.

Kumar, G.S., 2006. Free and bound phenolic antioxidants in Amla (Emblica officinalis) and turmeric (Curcuma longa), Journal of Food Compound Analysis 19, 446-452.

Li, J.W., Fan, L.P., Ding, S.D., Ding, S.L., 2007. Nutritional composition of five cultivars of Chinese jujube. Food Chemistry 103, 454-460.

Lowry, O.H., Rosebrugh, N.J., Farr, A.L., Randall, R.J., 1951. Protein measurement with folin phenol reagent., Journal of Biochemistry 193, 265-275.

Lu, H., Lou, H., Zheng, H., Hu, Y., Li, Y., 2012. Nondestructive evaluation of quality changes and the optimum time for harvesting during jujube (Zizyphus jujube Mill. cv. Changhong) fruits development. Food Bioprocess Technology 5(6), 2586-2595.

Marangoni, A., Alli, I., Kermasha, S., 1988. Composition and properties of seeds of the true legume Tamarindus indica. Journal of Food Science 53, 1452-1455.

Meillon, S., 1974. Process for making drinks, syrups, juice and liquor and solid extracts based on tamarind products thus obtained. French Patent No. 2231322 (English Summary).

Meillon, S., 1974. Process for making drinks, syrups, juice and liquor and solidextracts based on tamarind products thus obtained. French Patent No. 2231322 (English Summary). 
Morton, J., 1987. Indian Jujube. Http://www.hort. Purdue. edu/newcrop/morton/indian_jujube.

Narashimham, P., 1990. Breadfruit and jackfruit. In: Nagy, S., Shaw, P.E., Wardowski, W.F. (Eds.). Fruits of Tropical and Subtropical Origin Composition, Properties and Uses. Florida: Florida Science Source, Inc, 216-259.

Nayak, P., Tandon, D.K.,Bhatt, D.K., 2012. Study on changes of nutritional and organoleptic quality of flavored candy prepared from aonla (Emblica officinalis.) during storage. International Journal of Nutrition and health 4(7), 100-106.

Pareek, S., Dhaka, R.S., 2008. Association analysis for quality attributes in ber. Indian Journal Arid Horticulture, 3(1), 77-80

Parvez, S.S., Parvez, M.M., Nishihara, E., Gemma, H., Fujii, Y., 2003. Tamarindus indicaL. leaf is a source of allelopathic substance. Plant Growth Regulation 40(2)107-115.

Purseglove, J.W., 1987. Tropical Crops. Dicotyledons, Longman Science and Technology, 204-206.

Shankaracharya, N.B., 1998. Tamarind - Chemistry, Technology and Uses-a critical appraisal. Journal of Food Technology 35(3), 193-208.

Shanon, J., 1966. In: Methods of enzymatic analysis 2 (Ed Bergmcyer). Academic Press New York., 685.

Singh, U., Bradbury, J.H., 1988. HPLC determination of vitamin $A$ and vitamin D in South Pacific root crops, 45 (1), 87-94.

Somogyi, M., 1952. Notes on sugar estimation. Journal of Biology and Chemistry 200, 245.
Sultana, S., Ahmed, S., Jahangir, T., 2008. Emblica officinalis and hepatocarcinogenesis: A chemopreventive study in Wistar rats. Journal of Ethnopharmacology, 118, 1-6.

Teotia, S.S., Dubey, P.S., Awasthi, R.K., Upadhyay, N.P., 1974. Studies on physic-chemical characteristics of some important ber varieties (Ziziphus mauritiana Lamk.). Progress Horticulture 5(4), 81-88.

Timpa, J.D., Bruke, J.J., Quisenberry, J.E., Wendt, C.W., 1985. Carbohydrate utilizationunder stress. Novosibresic-USSR 5, 65-69.

USDA National Nutrient database. http://www.nutrition-andyou.com/lemon.html. Accessed on 12 January 2013.

Vijayakumari, B., Yadav, H.R., Parimaladevi, P., 2012. Enzymatic Antioxidant of Ficus Carica, Emblica Officinalis, Cephalandra Indica and Terminalia Chebula International Journal of Pharmacology and BioSciences 2(3), 426-430.

Vinson, J.A., Su, X., Zubik, L., Bose, P., 2001. Phenol antioxidant quantity and quality in foods: fruits. Journal of Agriculture and Food Chemistry 49, 5315-5321.

Beauchamp, C.O., Fridovich, I., 1971. Superoxide dismutase:improved assays and an assay applicable to acrylamide gels. Analytical Biochemistry 44, 276-287.

Wei, L.J., Shao-dong, D., Xiao-lin, D., 2005. Comparison of antioxidant apacities of extracts from five cultivars of Chinese jujube. Process Biochemistry 40, 3607-3613.

Wenkam, N.S., Miller, C.D., 1965. Composition of Hawaii Fruits. Hawaii Agriculture Experimental Station, University of Hawaii, Bulletin 135, 1965. 